\title{
Diastereochemical Differentiation of $\beta$-Amino Acids Using Host-Guest Complexes Studied by Fourier Transform Ion Cyclotron Resonance Mass Spectrometry
}

\author{
Anna R. M. Hyyryläinen, ' Jaana M. H. Pakarinen, ${ }^{a}$ Pirjo Vainiotalo, ${ }^{a}$ \\ Géza Stájer, ${ }^{\mathrm{b}}$ and Ferenc Fülöp ${ }^{\mathrm{b}}$ \\ ${ }^{a}$ Department of Chemistry, University of Joensuu, 80101 Joensuu, Finland \\ b Institute of Pharmaceutical Chemistry, University of Szeged, H-6701 Szeged, Hungary
}

\begin{abstract}
Host-guest complexes where tetraethyl resorcarene was the host molecule were used to study the stereoselectivity of diasteromeric pairs of di-endo- and di-exo-2,3-disubstituted norbornane and norbornene amino acids by ion-molecule reactions and collision-induced dissociation with electrospray ionization Fourier transform ion cyclotron resonance mass spectrometry (ESI FT-ICR MS). Both methods showed stereoselectivity for the diastereomeric pairs. Particularly high selectivity was achieved for di-endo- and di-exo-2,3-disubstituted norbornane amino acids with ion-molecule reactions. Also, ab initio and hybrid density functional theory calculations were performed to study the different structures of the host-guest complexes. Hydrogen bonding was crucial for the calculated lowest energy structures, and sterical considerations satisfactorily explained the ion-molecule reaction results. (J Am Soc Mass Spectrom 2007, 18, 1038-1045) (C 2007 American Society for Mass Spectrometry
\end{abstract}

$\mathrm{D}$ etermination of the stereochemistry of natural products and pharmaceutically interesting substances is important in present medical science and related areas. Although mass spectrometry is a rapid analytical technique of unparalleled sensitivity, differentiating stereoisomers by mass spectrometry has proved to be a challenging problem. Classical ionization techniques such as electron and chemical ionization have been used in stereochemical differentiation, with varying degrees of success [1]. Presently, electrospray ionization is mostly used [2-5].

Among the methods for obtaining stereochemical differentiation by mass spectrometry, collision-induced dissociation (CID) has become popular because of the simplicity and easy availability of the technique [6-8]. Ion-molecule reactions have also been used to differentiate various types of stereoisomers (both enantiomers and diastereomers) [9, 10]. Host-guest chemistry involving ion-molecule reactions or isotopic labeling has been useful in chiral molecular recognition [11-13]. Most notably, Lebrilla et al. used ion-molecule reactions and host-guest complexes, with cyclodextrin as host molecule, to differentiate enantiomers and to achieve chiral recognition $[4,14,15]$. The enantioselectivity appears in the different reaction rates of the enantiomers in the gas-phase reactions. Dearden et al.

Address reprint requests to Dr. Pirjo Vainiotalo, University of Joensuu, Department of Chemistry, P.O. Box 111, FI-80101 Joensuu, Finland. E-mail: pirjo.vainiotalo@joensuu.fi also used host-guest complexes, achieving chiral differentiation by measurement of equilibrium constants for guest exchange with a chiral host $[5,16]$.

The rigid norbornane skeleton is highly suitable for the examination of stereochemical interactions of functional groups by mass spectrometry because the stereochemical positions of the groups in the molecule are exactly known. Ion-molecule reactions allow di-endoand di-exo-2,3-disubstituted norbornane derivatives to be distinguished to some extent from their endo-exo isomers [17, 18], but so far there has been no mass spectrometric method capable of differentiating between the di-endo- and di-exo-2,3-isomers themselves.

In the present study, we show that ion-molecule reactions involving guest exchange of host-guest complexes and CID of the complexes are promising methods for the differentiation of diastereomeric diendo- and di-exo-2,3-disubstituted norbornane and norbornene amino acids. The host molecule for the study, tetraethyl resorcarene (1), is presented in Scheme $\mathbf{1}$.

Resorcarene is a cyclic tetramer of resorcinol where the resorcinol rings are connected with methylene bridges [19]. The upper rim consists of eight hydroxyl groups and the lower rim of alkyl chains. Resorcarenes are especially mentioned as the hosts for quaternary ammonium compounds and appear to be the strongest known complexing agents for methyl ammonium derivatives $[19,20]$. Tetraethyl resorcarene also easily forms protonated host-guest complexes with the diastereomeric $\beta$-amino acids ( $\boldsymbol{\beta}$-AC) 2-5 (Scheme 2). 


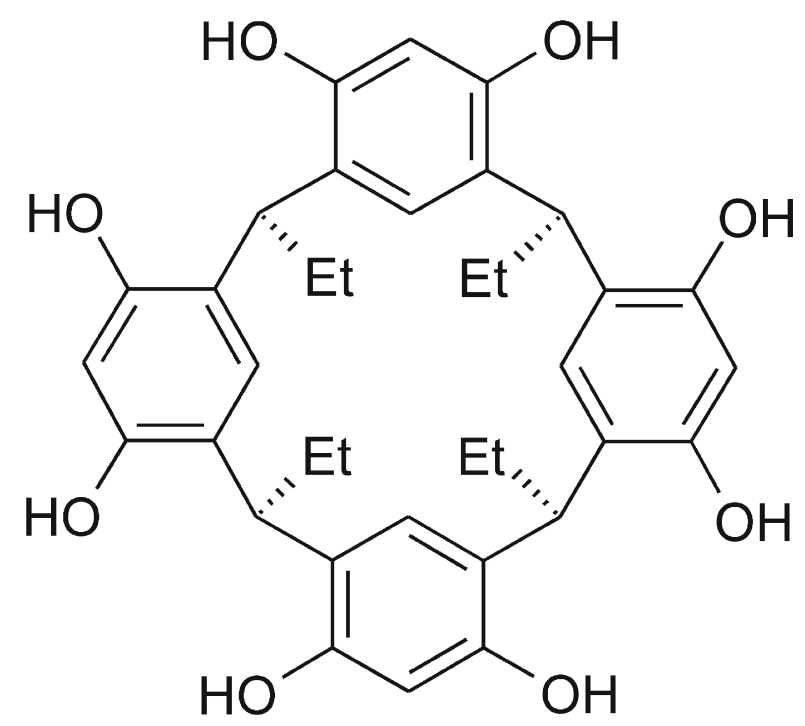

Scheme 1. Tetraethyl resorcarene (1) used as the host compound.

$\beta$-Amino acids are important natural compounds, some of them exhibiting antibacterial activity. They are also used as precursors for $\beta$-lactams and in drug research [21].

Two diastereomeric pairs of $\beta$-amino acids were studied: di-endo- and di-exo-2,3-disubstituted norbornane amino acids and the corresponding di-endo- and di-exo2,3-disubstituted norbornene amino acids (saturated and unsaturated $\beta$-amino acids). 2,3-Disubstituted norbornane and norbornene amino acids were both studied to evaluate the effect of the double bond in the norbornane skeleton on the diastereoselectivity. In addition, quantitative analysis of the acids was performed to study whether ion-molecule reactions can be used to determine the mole fractions of isomers in "unknown" samples. In turn, CID experiments were performed with the hostguest complexes to study whether diastereochemical differentiation can be achieved in this way. $\mathrm{E}_{\mathrm{com}}(50 \%)$ values of the host-guest complexes were calculated from the decomposition curves and diastereochemical differentiation was evaluated as the ratio of $\mathrm{E}_{\mathrm{com}}(50 \%)$ values. As well, ab initio and hybrid density functional theory calculations were performed to evaluate the structures of the different host-guest complexes.

\section{Experimental}

All the mass spectrometry experiments were performed with a Fourier transform ion cyclotron resonance (FT-ICR) mass spectrometer (Bruker BioApex 47e, Bruker Daltonics, Billerica, MA, USA) with a 4.7 Tesla superconducting magnet and an external Apollo ${ }^{\mathrm{TM}}$ electrospray ionization (ESI) source. The base pressure of $1.0 \times 10^{-10}$ Torr was maintained by rotary vacuum and turbomolecular pumps supplied by Edwards (Edwards High Vacuum International, Crawley, UK). The sample was introduced to the mass spectrometer by a $70^{\circ}$ off-axis sprayer at a rate of $90 \mu \mathrm{L} / \mathrm{h}$. Nitrogen gas heated at $60{ }^{\circ} \mathrm{C}$ was used as a nebulization and countercurrent drying gas. Parameters of the ion source were optimized so that the intensity of the precursor ion, the stability, and the signal-to-noise ratio were optimal. Ion-source parameters were adjusted to $-3.6 \mathrm{kV}$ to the end plate and to $-4.0 \mathrm{kV}$ to the metal-coated glass capillary. All measurements were repeated at least once with good reproducibility and the results are given as average values. The measurements and data handling were performed with Bruker XMASS software version 6.0.2.

In ion-molecule reactions, neutral propylamine was purified in the vacuum manifold in at least three freeze-thaw cycles before it was leaked to the analyzer cell through a variable leak valve. The pressure of the cell was allowed to rise to $5.0 \times 10^{-8}$ Torr as a result of the propylamine and the pressure was kept constant during the measurements. The host-guest complex ion was isolated by the CHEF (correlated harmonic excita-

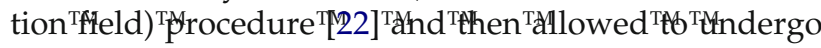
a guest-exchange reaction with gaseous propylamine. The reaction time varied from $0.1 \mathrm{~s}$ to as much as $500 \mathrm{~s}$. The spectra usually consisted of 16 summed scans with dataset of $256 \mathrm{~K}$, but with longer reaction times eight, six, or four scans were carried out. Variation in the number of scans did not influence the information obtained from the resulting spectra because the only interest was the relative intensities of the precursor and product ion peaks. Identical conditions were used for the two members of the diastereomeric pair, and all ion-molecule reaction spectra were background corrected.

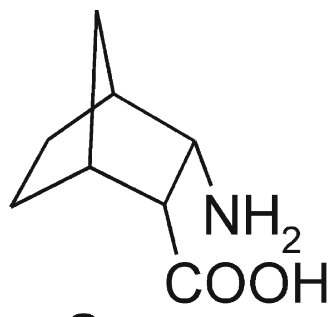

2

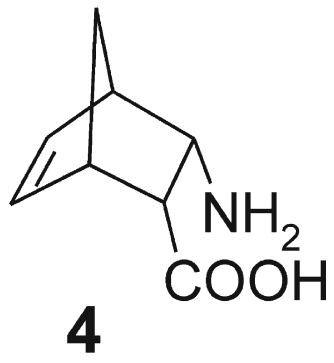

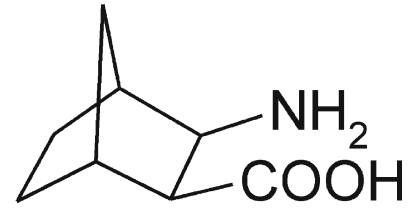

3

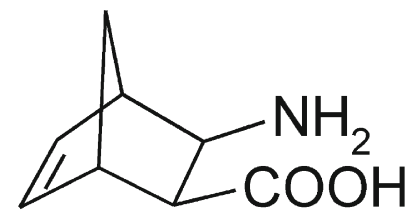

5
Scheme 2. Di-endo- and di-exo-2,3-disubstituted norbornane amino acids ( 2 and 3 ) and di-endo- and di-exo-2,3-disubstituted norbornene amino acids ( 4 and 5 ) used as the guest compounds. 
In CID experiments, the host-guest complex ion was isolated by the CHEF procedure, translationally activated by an on-resonance radio frequency (RF) pulse, and allowed to collide with pulsed argon gas to achieve dissociation. Monoisotopic isolations were avoided because single-frequency activation shots were observed to bring additional energy to the complexes. Duration of the activation pulse was $2 \mathrm{~ms}$ with delay of $3 \mathrm{~s}$. Each spectrum is a sum of 16 scans with dataset of $256 \mathrm{~K}$ and all parameters for diastereomers were kept constant during the measurements. The spectra were measured as a function of ion kinetic energy by varying the amplitude of the activation pulse. $E_{\text {com }}$ values were calculated from experimental parameters using equations ${ }^{\mathrm{T}}$ presented ${ }^{\mathrm{T}}$ earlier ${ }^{\mathrm{T}}[23]$.

The host molecule, tetraethyl resorcarene (1), was

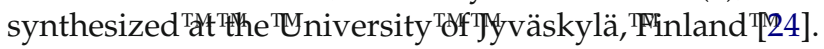
Synthesis and characterization of the diastereomeric guest compounds (2-5) were reported previously

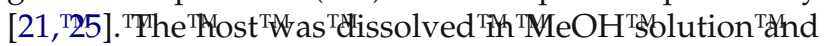
the guests were dissolved in 1:1 $\mathrm{MeOH} / \mathrm{H}_{2} \mathrm{O}$ solution with a concentration of $1 \mathrm{mM}$. The complexes were prepared by mixing the host and guest in ratio $1: 1$, the final concentrations of both host and guest in the $\mathrm{MeOH}$ solution being $1.0 \times 10^{-5} \mathrm{M}$. Propylamine used as a neutral reagent in ion-molecule experiments was obtained from Sigma Chemical Co. (St. Louis, MO, USA).

$\mathrm{Ab}$ initio and hybrid density functional theory (DFT)

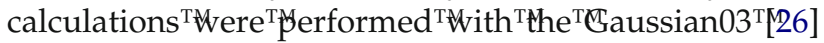
series of programs on Sun Fire $25 \mathrm{~K}$ hardware at the Center for Scientific Computing (CSC) in Espoo and on Intel Pentium 4 Xeon hardware at the University of Joensuu. First, both the neutral host, tetraethyl resorcarene (1), and the four protonated guest molecules, $\beta$-amino acids (2-5), were optimized separately using a restricted Hartree-Fock (RHF) procedure and the 3-21G basis set. For tetraethyl resorcarene, the crown conformation containing four intramolecular hydrogen bonds was chosen because it was previously found to be the

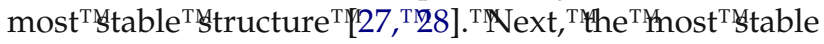
conformation of each protonated guest molecule was repeatedly placed randomly inside the cavity of the tetraethyl resorcarene in various positions and each time fully optimized to find different structures of the host-guest complexes. Because of the difference in the relative energies of the structures of the host-guest complexes estimated with different basis sets, all found structures (altogether 13, whose relative energies were $<20 \mathrm{~kJ} / \mathrm{mol}$ ) were examined in a stepwise manner by use of RHF/6-31G(d) and density functional calculations with the B3LYP/6-31G(d) basis set. Final optimized geometries and energies were obtained using B3LYP/6-31G(d,p) level of theory. Harmonic frequency analysis of host-guest complexes was done with the RHF/3-21G basis set. Because no imaginary frequencies were obtained, the structures correspond to the true equilibrium configuration. Structures were visualized with ${ }^{\mathrm{T}}$ Gauss View ${ }^{\mathrm{T}}$ ! $0^{\mathrm{T}}[29]$.

\section{Results and Discussion}

\section{Ion-Molecule Reactions}

The success of chiral analysis based on ion-molecule

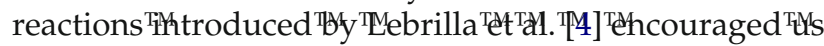
to apply the method for diastereochemical differentiation of the $\beta$-amino acid diastereomers (2-5). Propylamine, which readily forms complexes with tetra-

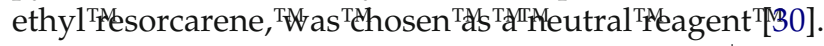
In the gas phase the host-guest $[\mathbf{1}: \boldsymbol{\beta}-\mathbf{A C}+\mathbf{H}]^{+}$complexes react with neutral propylamine $\left(\mathbf{P r N H}_{2}\right)$ at different rates, forming complex $\left[\mathbf{1}: \mathbf{P r N H}_{\mathbf{2}}+\mathbf{H}\right]^{+}(\mathrm{Eq} 1)$.

$$
[1: \beta-\mathrm{AC}+\mathrm{H}]^{+}+\mathrm{PrNH}_{2} \rightarrow\left[1: \mathrm{PrNH}_{2}+\mathrm{H}\right]^{+}+\beta-\mathrm{AC}
$$

In the basic measurements the $[\mathbf{1}: \boldsymbol{\beta}-\mathbf{A C}+\mathbf{H}]^{+}$complex ion was observed as the most abundant ion with all four diastereomeric guest molecules. Ions $[\mathbf{1}+\mathbf{H}]^{+},[\mathbf{1}+\mathbf{N a}]^{+}$, $[\mathbf{1}+\mathbf{K}]^{+}$, and $[\boldsymbol{\beta}-\mathbf{A C}+\mathbf{H}]^{+}$were also observed, but they were entirely ejected before the ion-molecule reactions. To obtain the rate constants $(k)$, the abundances of the precursor $[\mathbf{1}: \boldsymbol{\beta}-\mathbf{A C}+\mathbf{H}]^{+}$and product $\left[\mathbf{1}: \mathbf{P r N H}_{2}+\mathbf{H}\right]^{+}$ ions were measured as a function of time. Rate constants $(k)$ were obtained from the slopes of the pseudo-first-order rate plots $\ln \mathrm{I} / \mathrm{I}_{0}$ versus $t$ introduced by Lebrilla et al., where I is the intensity of the precursor complex at time $t$ and $I_{0}$ is the sum of the intensities of the precursor and

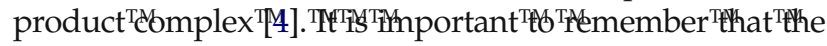
measured absolute rates are not accurate, mainly because pressure and temperature in the analyzer cell are not exactly known. The main thing in this study, however, is the diastereoselectivity $\left[\mathrm{S}_{\mathrm{d}}(\right.$ diendo/diexo $\left.)\right]$, which is defined as the ratio $\mathrm{k}_{\text {diendo }} / \mathrm{k}_{\text {diexo }}$. In this ratio, any deviation in pressure or temperature from the true value is completely eliminated. If the value of diastereoselectivity is 1.0 , isomers cannot be distinguished from each other by ionmolecule reactions.

Di-endo- and di-exo-2,3-disubstituted norbornane amino acids ( 2 and 3 ) were easily distinguished from each other in ion-molecule reactions. As can be seen in

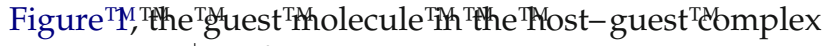
$[\mathbf{1}: \mathbf{2}+\mathbf{H}]^{+}(\mathrm{m} / \mathrm{z}$ 756) was replaced by propylamine much faster than the guest molecule in the host-guest complex $[\mathbf{1}: \mathbf{3}+\mathbf{H}]^{+}$. In the complex with the di-endo isomer (2), the guest was totally replaced by 200-s reaction time, but in the case of the di-exo isomer (3) the total guest exchange required as much as $500 \mathrm{~s}$.

The reaction rate plots for the exchange reactions of di-endo- and di-exo-2,3-disubstituted norbornane amino

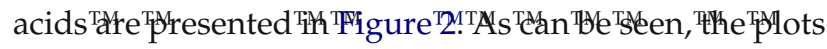
are not straight. Lebrilla et al. noticed this same kind of behavior in the chiral differentiation of pharmaceutical compounds using ion-molecule reactions with cyclo-

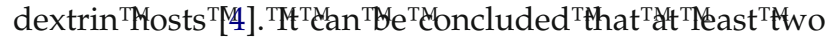
kinds of complexes are formed: fast and slow reacting. In the case of short reaction times $(<25 \mathrm{~s})$, the fast reacting complexes dominated. The total amount of the 
(a)
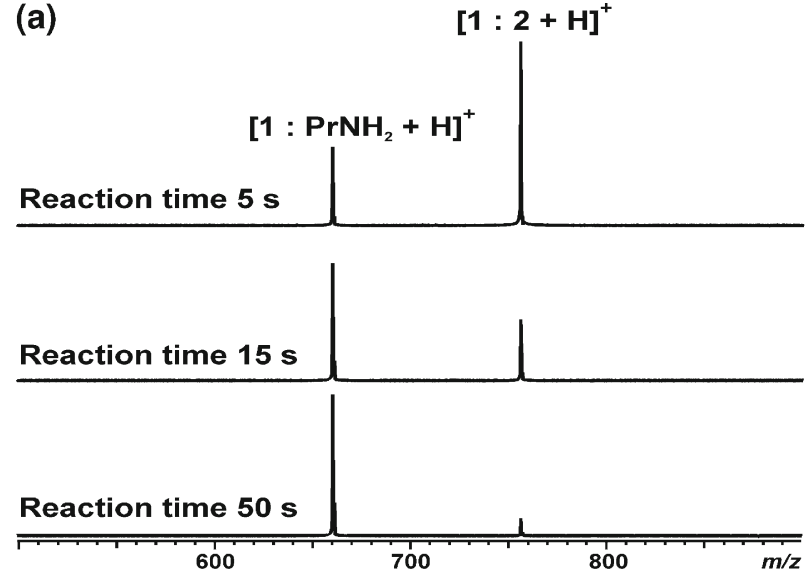

(b)

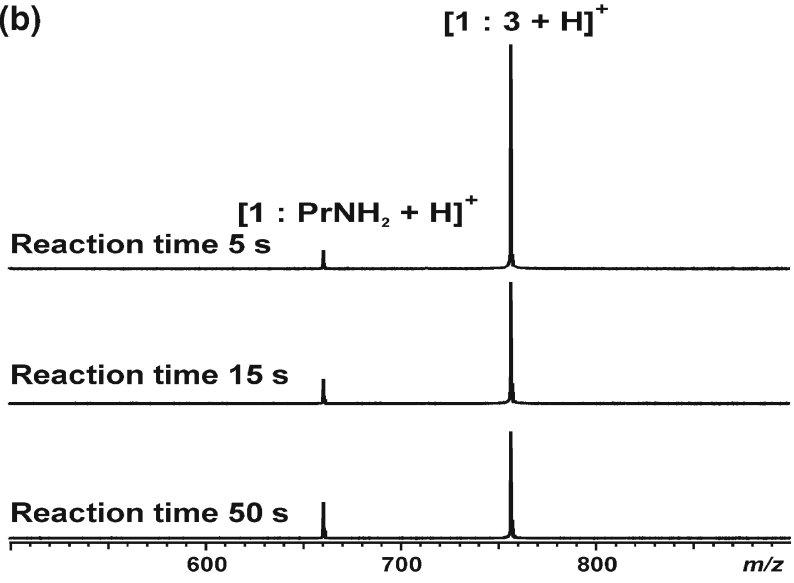

Figure 1. ESI mass spectra of ion-molecule reactions of hostguest complexes of tetraethyl resorcarene and protonated (a) di-endo- and (b) di-exo-2,3-disubstituted norbornane amino acid with propylamine.

fast reacting complexes was not large, however, and rate constants were measured only for the slower reactions.

The rate constant measured for the slower exchange reaction of di-endo-2,3-disubstituted norbornane amino acid $\left(k_{\text {diendo }}\right)$ was $3.11 \times 10^{-11} \mathrm{~cm}^{3} \mathrm{~s}^{-1} \mathrm{~mol}^{-1}$ and that for di-exo-2,3-disubstituted norbornane amino acid $\left(k_{\text {diexo }}\right)$ was $0.24 \times 10^{-11} \mathrm{~cm}^{3} \mathrm{~s}^{-1} \mathrm{~mol}^{-1}$. The level of diastereoselectivity for the 2,3-disubstituted norbornane amino acids is as high as 13.0, with the di-endo isomer (2) being replaced much faster. The high value of diastereoselectivity indicates that steric interactions strongly influence the reaction rate.

The diastereoselectivity was much lower for the 2,3-disubstituted norbornene amino acids (Scheme 2, compounds 4 and 5) than for the norbornane amino acids. Now the guest molecule in the host-guest complex $[\mathbf{1}: \mathbf{5}+\mathbf{H}]^{+}(m / z 754)$ was replaced by propylamine faster than the guest molecule in the host-guest com-

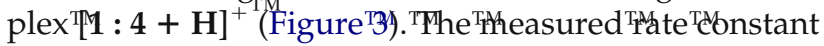
for the exchange reaction of di-endo-2,3-disubstituted norbornene amino acid $(4)\left(k_{\text {diendo }}\right)$ was $0.74 \times 10^{-11} \mathrm{~cm}^{3}$ $\mathrm{s}^{-1} \mathrm{~mol}^{-1}$, and that for di-exo-2,3-disubstituted nor- bornene amino acid (5) $\left(k_{\text {diexo }}\right)$ was $1.52 \times 10^{-11} \mathrm{~cm}^{3} \mathrm{~s}^{-1}$

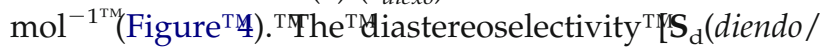
diexo)] for the 2,3-disubstituted norbornene amino acids is therefore 0.5. It is surprising to find such a large difference in the diastereoselectivities of the 2,3disubstituted norbornene and norbornane amino acids when the only difference is the double bond in the norbornane skeleton. Because the amount of fast reacting complexes in the ion-molecule reactions was somewhat larger for the 2,3-disubstituted norbornene amino acids (4 and 5) than that for the 2,3-disubstituted norbornane amino acids ( 2 and 3 ), in the case of the 2,3-disubstituted norbornene amino acids we also measured rate constants for the fast reactions. The rate constant for the fast exchange reaction of di-endo-2,3disubstituted norbornene amino acid $\left(k_{\text {diendo, fast }}\right)$ was $3.93 \times 10^{-11} \mathrm{~cm}^{3} \mathrm{~s}^{-1} \mathrm{~mol}^{-1}$, whereas that for di-exo-2,3disubstituted norbornene amino acid $\left(k_{\text {diexo, fast }}\right)$ was $5.31 \times 10^{-11} \mathrm{~cm}^{3} \mathrm{~s}^{-1} \mathrm{~mol}^{-1}$. The diastereoselectivity was thus 0.7. Because the diastereoselectivity was also lower with the fast than with the slower reactions, the emphasis is consequently on the slower reactions.

It is also possible to measure diastereospecificity quantitatively using ion-molecule reactions. In these measurements, reactions were performed at the reaction time where the difference in relative intensities of the precursor and product for the two diastereomers
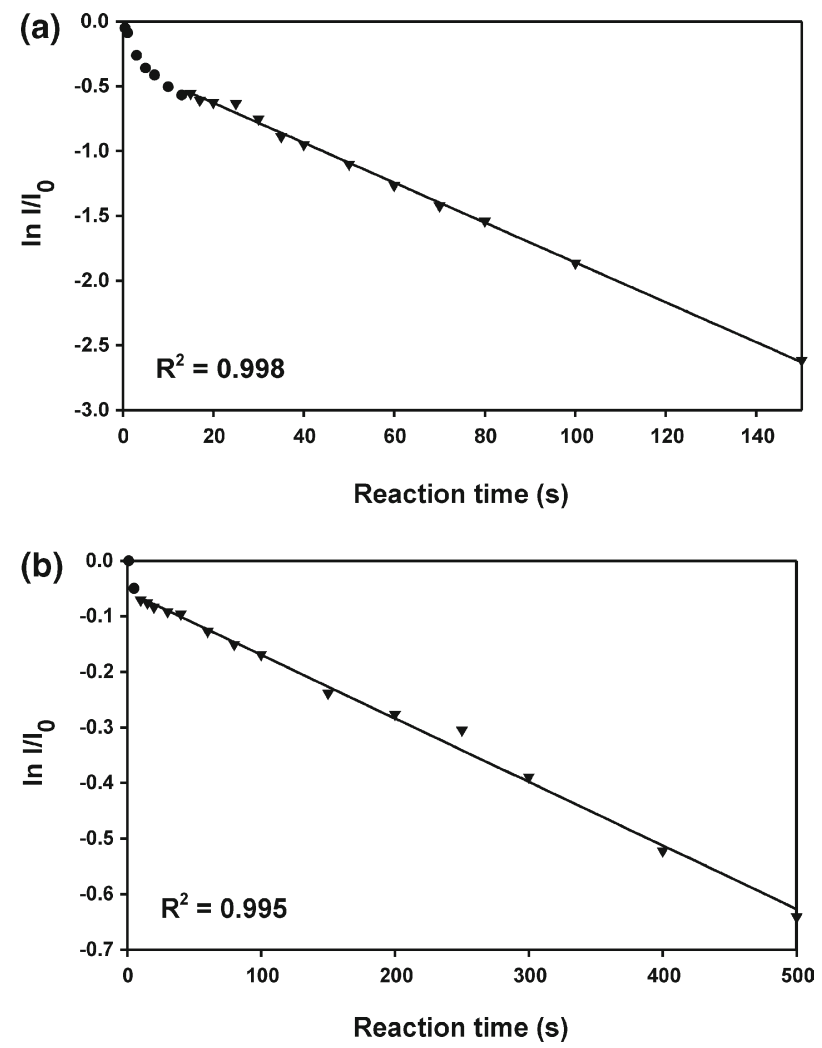

Figure 2. Reaction rate plots for reactions between complexes of tetraethyl resorcarene with protonated (a) di-endo- and (b) di-exo2,3-disubstituted norbornane amino acid and propylamine. 
was largest (80 s). Calibration curves were constructed on the basis of the analysis of nine diastereomeric mixtures, beginning with one pure diastereomer $(1: 0)$ and ending with the other $(0: 1)$. The mass spectra of the different mixtures were measured and, applying linear regression, the calibration curves were obtained by plotting the ratio of the relative intensity of the product complex (I) to the sum of the relative intensities of the product and the precursor complex $\left(\mathrm{I}_{0}\right)$ against the mole

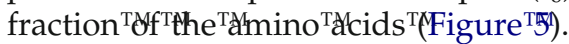

Two "unknown" diastereomeric mixtures were analyzed under the same reaction conditions as those under which the calibration curve was constructed. The "unknown" mixtures contained mole fractions of 0.10 and 0.90 of di-endo-2,3-disubstituted norbornane amino acid. Both measurements were carried out on five separate samples and, each time, basic and isolated precursor ion mass spectra were measured before the reaction. With reference made to the calibration curve, the average mole fractions of di-endo-2,3-disubstituted norbornane amino acid in the two mixtures were calculated to be $0.11 \pm 0.01$ and $0.86 \pm 0.01$.

Similarly, in the case of 2,3-disubstituted norbornene amino acids, we analyzed two "unknown" diastereo-

(a)

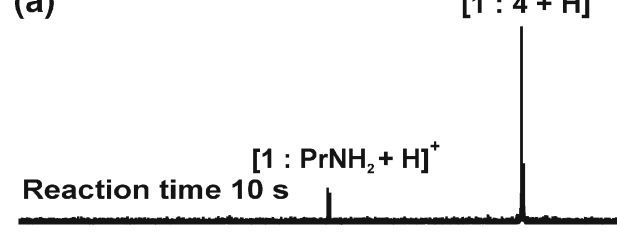

Reaction time $40 \mathrm{~s}$

Reaction time $70 \mathrm{~s}$

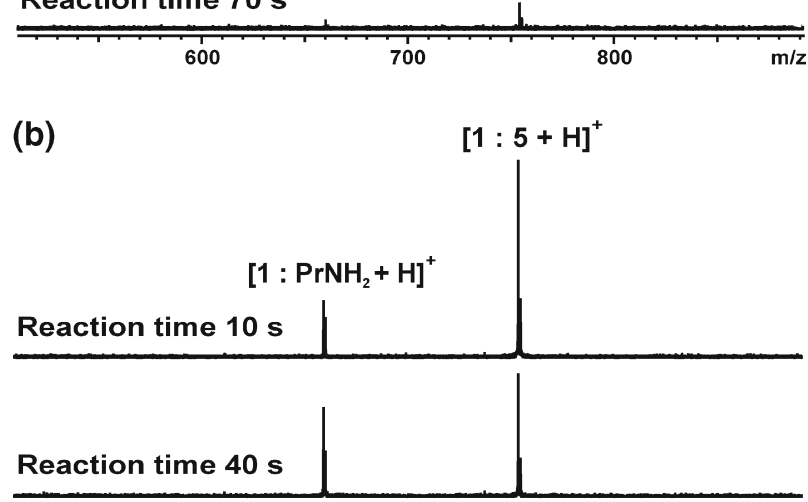

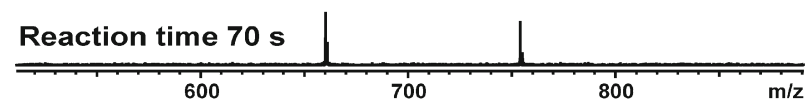

Figure 3. ESI mass spectra of ion-molecule reactions of hostguest complexes of tetraethyl resorcarene and protonated (a) di-endo- and (b) di-exo-2,3-disubstituted norbornene amino acid with propylamine.
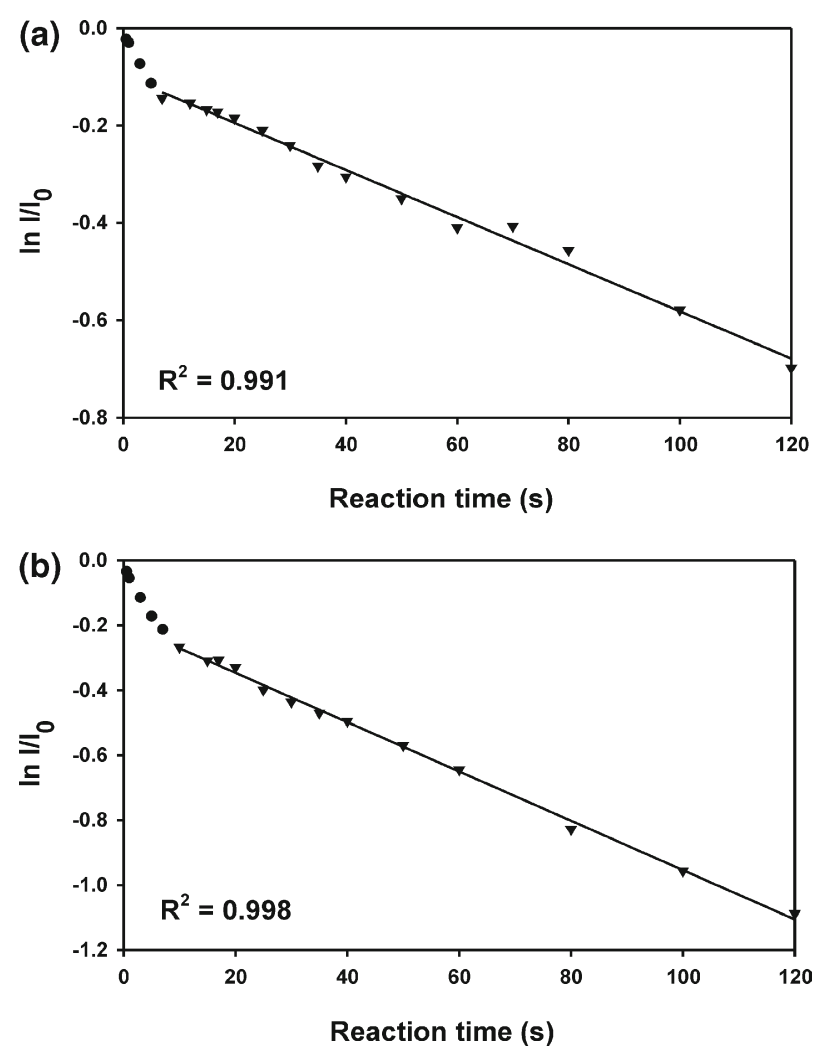

Figure 4. Reaction rate plots for reactions between complexes of tetraethyl resorcarene with protonated (a) di-endo- and (b) di-exo2,3-disubstituted norbornene amino acid and propylamine.

meric mixtures with mole fractions of 0.1 and 0.50 of di-exo-2,3-disubstituted norbornene amino acid. With reference made to the calibration curve $\left(R^{2}=0.975\right)$, the average mole fractions of the di-exo isomer were calculated to be $0.13 \pm 0.06$ and $0.50 \pm 0.03$.

\section{Collision-Induced Dissociation}

CID experiments were performed to study whether the diastereoselectivity of the 2,3-disubstituted norbornane ( 2 and 3 ) and norbornene ( 4 and 5 ) amino acids could be

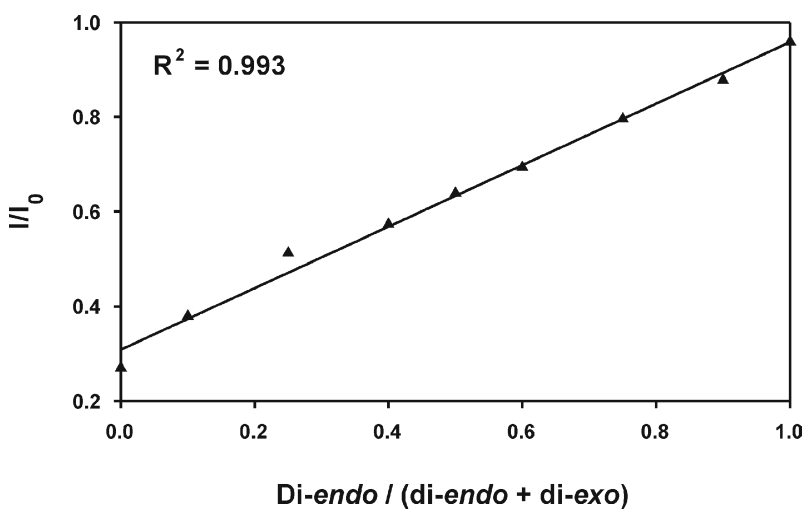

Figure 5. Calibration plot for the reactions of mixtures of complexes of tetraethyl resorcarene and protonated 2,3-disubstituted norbornane amino acid diastereomers with propylamine. 


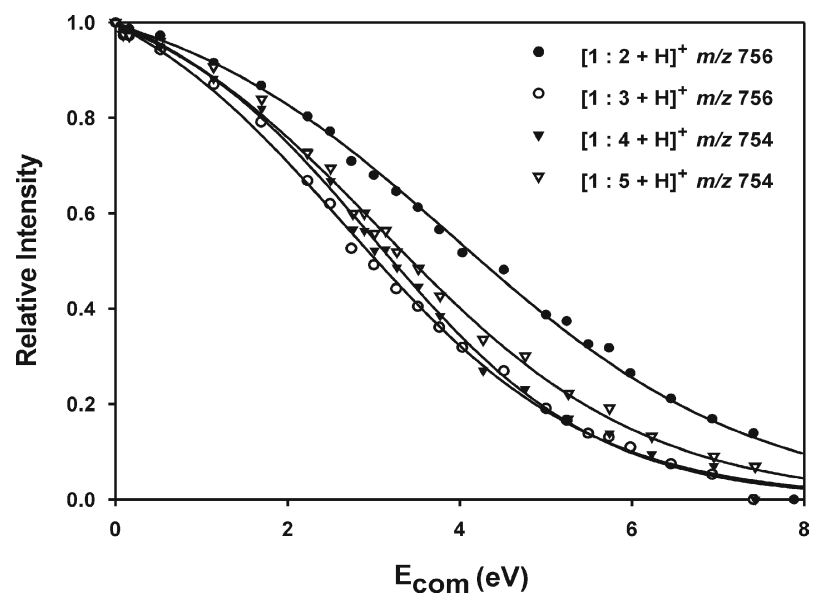

Figure 6. Decomposition curves for complexes of tetraethyl resorcarene (1) with 2,3-disubstituted norbornane (2 and 3) and norbornene (4 and 5 ) amino acids.

determined through decomposition of the host-guest complexes. All complexes dissociated, forming the protonated guest molecule $[\boldsymbol{\beta} \text {-AC }+\mathbf{H}]^{+}$with high abundance, but also the peak $[\mathbf{1}+\mathbf{H}]^{+}(m / z$ 601) was observed in both di-endo-2,3-disubstituted norbornane and di-endo-2,3-disubstituted norbornene amino acid mass spectra. These findings suggest that proton affinity of the guest molecules is slightly higher than the proton affinity of the host molecule. Decomposition of the complexes as a function of kinetic energy is pre-

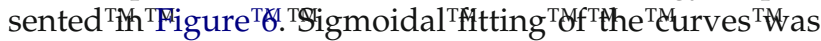
used because this best illustrates the decomposition in the gas phase. $\mathrm{E}_{\text {com }}(50 \%)$ values, which represent the activation energy at which half of the isolated complex has decomposed, were calculated and diastereoselectivity was evaluated on the basis of the ratio of $\mathrm{E}_{\mathrm{com}}(50 \%)$ values of the two isomers.

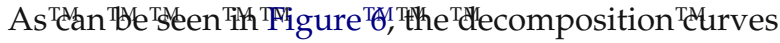
reveal differences in the kinetic stability of the 2,3disubstituted norbornane amino acid isomer complexes. The $\mathrm{E}_{\mathrm{com}}(50 \%)$ value for the complex of tetraethyl resorcarene with protonated di-endo-2,3disubstituted norbornane amino acid $[\mathbf{1}: \mathbf{2}+\mathbf{H}]^{+}$is 4.6 $\mathrm{eV}$ and that for the corresponding complex with di-exo-

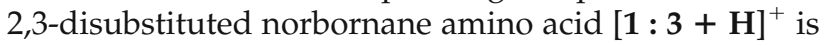
$3.2 \mathrm{eV}$. Defined as the ratio $\mathrm{E}_{\mathrm{com}}(50 \%)_{\text {diendo }} /$ $\mathrm{E}_{\mathrm{com}}(50 \%)_{\text {diexo, }}$ the diastereoselectivity $\left[\mathrm{S}_{\mathrm{d}}(\right.$ diendo/diexo $\left.)\right]$ is 1.4. The result shows that the host-guest complex formed with the di-endo isomer is kinetically more stable because it requires more energy for decomposition than the corresponding complex with the di-exo isomer. Correspondingly, the $\mathrm{E}_{\mathrm{com}}(50 \%)$ value for the complex of tetraethyl resorcarene with protonated diendo-2,3-disubstituted norbornene amino acid $[\mathbf{1}: 4+\mathbf{H}]^{+}$ is $3.2 \mathrm{eV}$ and that for the complex with di-exo-2,3disubstituted norbornene amino acid $[\mathbf{1}: 5+\mathbf{H}]^{+}$is 3.5 $\mathrm{eV}$. The diastereoselectivity is now 0.9 . The results show that the diastereoselectivity of the studied diastereomers can also be determined with CID experiments.
Ion-molecule reactions nevertheless appear to be more suitable for diastereochemical differentiation because decomposition of the host-guest complexes does not reveal large differences between the isomers.

\section{Theoretical Calculations}

$\mathrm{Ab}$ initio and hybrid density functional theory calculations were performed to clarify the results obtained by mass spectrometry. Because of the large size of hostguest complexes, so far only a few theoretical studies have included the use of the computationally expensive $\mathrm{ab}$ initio and density functional theory calculations

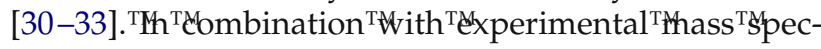
trometric work, calculations were made earlier for the different conformations of tetraethyl resorcarene and also of its alkali metal and ammonium ion complexes

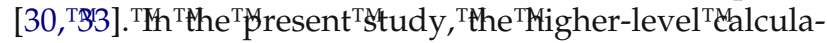
tions were used in full-geometry optimizations and several different structures were found for the complexes of tetraethyl resorcarene with protonated 2,3disubstituted norbornane and norbornene amino acids. This would appear to support the observation of slow and fast reacting complexes in the ion-molecule reactions.

The differences in relative energies of the several protonated host-guest complexes were calculated to be small. At the highest level of calculations [B3LYP/6$31 G(d, p)]$ there were two and three different structures for di-endo- and di-exo-2,3-disubstituted norbornane amino acid complexes (relative energies $<11.4 \mathrm{~kJ} / \mathrm{mol}$ ), and two and four different structures for di-endo- and di-exo-2,3-disubstituted norbornene amino acid complexes (relative energies $<13.6 \mathrm{~kJ} / \mathrm{mol}$ ). The most stable structures for the host-guest complexes with protonated 2,3-disubstituted norbornane and norbornene

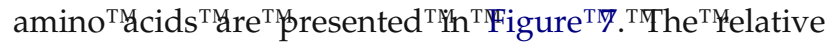

(a)

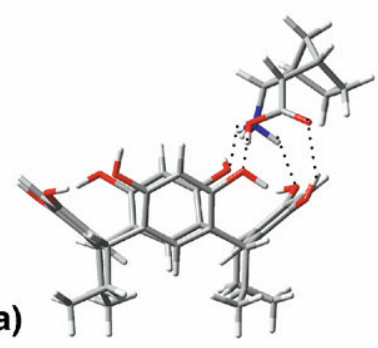

(c)

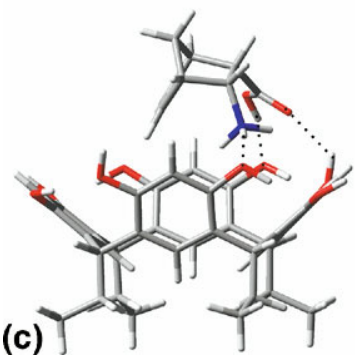

(b)
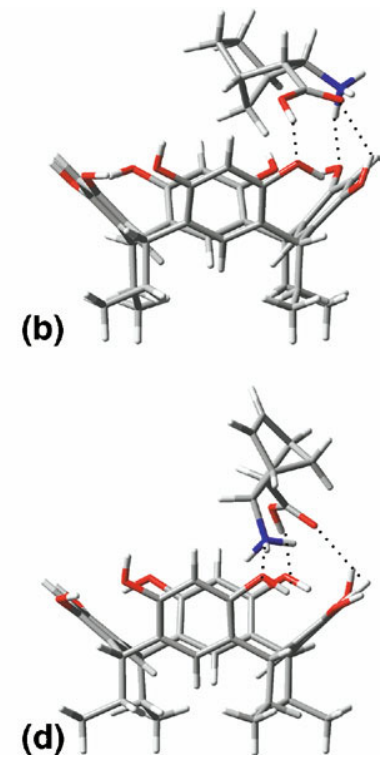

Figure 7. The lowest energy B3LYP/6-31G(d,p) structures for host-guest complexes (a) $[1: 2+\mathrm{H}]^{+},\left(\right.$b) $[1: 3+\mathrm{H}]^{+}$, (c) $[1: 4+$ $\mathrm{H}]^{+}$, and (d) $[1: 5+\mathbf{H}]^{+}$. 
energies of the diastereomeric pair of complexes was calculated to be 0 and $-2.9 \mathrm{~kJ} / \mathrm{mol}$ for $[\mathbf{1}: \mathbf{2}+\mathbf{H}]^{+}$and $[\mathbf{1}: \mathbf{3}+\mathbf{H}]^{+}$and 0 and $13.6 \mathrm{~kJ} / \mathrm{mol}$ for $[\mathbf{1}: \mathbf{4}+\mathbf{H}]^{+}$and $[1: 5+\mathbf{H}]^{+}$. For all host-guest complexes studied, hydrogen bonds were formed between the functional groups of the $\beta$-amino acid and the hydroxyl groups of the tetraethyl resorcarene. Moreover, all the diastereomeric guest molecules had an intramolecular hydrogen bond between the amino group and the carbonyl group. The complexation of the protonated guest molecule was also observed to affect the molecular skeleton of the host molecule, causing a conformational change from crown ${ }^{\mathrm{T}} \mathrm{H}^{\mathrm{T}}$ flattened ${ }^{\mathrm{T}} \mathrm{crown}^{\mathrm{T}}[\mathrm{B} 3]$.

The calculated lowest energy structures show that di-endo-2,3-disubstituted norbornane amino acid is perched on the edge of the upper rim of the host molecule ${ }^{\mathrm{T}}\left(\right.$ Figure $\left.^{\mathrm{T}} \mathrm{Pa}\right)$, ${ }^{\mathrm{T}}$ Whereas ${ }^{\mathrm{T}}$ di-exo-2,3-disubstituted norbornane amino acid is perched at some distance

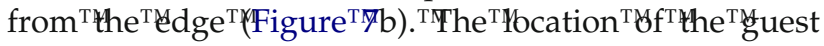
molecule is the main reason why in the ion-molecule reactions the di-endo isomer is replaced by propylamine clearly faster than the corresponding di-exo isomer. To form the new host-guest complex, the approaching propylamine molecule requires a proton from the protonated amino group of the $\beta$-amino acid. In addition, propylamine has to come near to the host cavity from the right direction. These requirements are achieved with the host-guest complex where di-endo isomer is the guest molecule, but not where it is the di-exo isomer. In the case of the di-exo isomer the location of the amino group decelerates the formation of the new host-guest complex.

In the case of the unsaturated $\beta$-amino acids, no marked difference was observed in the reaction rates of the two diastereomers. Again, this is easily explained by examining the lowest-energy complex structures. Di-endo-2,3-disubstituted norbornene amino acid is perched on the upper rim of the host molecule almost directly above the molecular cavity and the di-exo isomer is perched on the edge of the cavity of the host

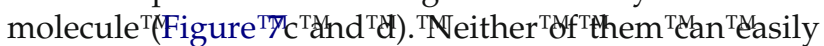
be replaced by the neutral reagent. According to the ion-molecule ${ }^{\mathrm{T}}$ reactions, ${ }^{\mathrm{T}}$ the ${ }^{\mathrm{T}} \mathrm{di}$-exo isomer $^{\mathrm{T}}\left(\mathrm{Figure}{ }^{\mathrm{T}} \mathrm{F} \mathrm{d}\right)$ was replaced by propylamine a little bit faster than was the di-endo isomer. The explanation behind this is that the cavity in the complex structure of the di-exo isomer is slightly more open, allowing easier access of the propylamine. With the di-endo isomer, the guest molecule tends to block the entrance of the approaching propylamine to the cavity of the host molecule.

\section{Conclusions}

Tetraethyl resorcarene proved to be a good host molecule for the $\beta$-amino acids studied. Host-guest complexes were easily formed and the reaction rates were sensitive to the stereochemistry of the guest molecules. This is the first time that the resorcarene host has been used for the differentiation of diastereomers. The ver- satility of Fourier transform ion cyclotron resonance mass spectrometry coupled with electrospray ionization was well demonstrated. Diastereoselectivity of di-endo- and di-exo-2,3-disubstituted norbornane and norbornene amino acids was achieved with both ionmolecule reactions and collision-induced dissociation mass spectrometry. In addition to this, several different structures and the binding nature of the host-guest complexes were evaluated theoretically with ab initio and hybrid density functional theory calculations.

Ion-molecule reactions, where the guest molecule in a host-guest complex is replaced by another guest, showed high diastereoselectivity for 2,3-disubstituted norbornane amino acid but only moderate selectivity for the corresponding 2,3-disubstituted norbornene amino acid. This was the case even though the only difference between the molecules is the double bond in the norbornane skeleton. The explanation of this behavior may be that the double bond stiffens the structure of the unsaturated guest molecules, causing them to bind differently from the saturated guest molecules. The experimental results were satisfactorily explained by the results of theoretical calculations, confirming the usefulness of such calculations. The results also showed that quantitative analysis based on ion-molecule reactions is applicable for both diastereomeric norbornane and norbornene amino acids.

CID mass spectra measured as a function of ion kinetic energy also revealed differences in the diastereomers. In this case, diastereoselectivity was determined from the calculated $\mathrm{E}_{\mathrm{com}}(50 \%)$ values. Diastereoselectivity was achieved for both norbornane and norbornene amino acids, although the values were not as high as for the ion-molecule reactions. The usefulness of ion-molecule reactions in structural studies is thus emphasized.

\section{Acknowledgments}

Funding provided by the Finnish Cultural Foundation and the Graduate School of Bioorganic and Medicinal Chemistry is gratefully acknowledged. The authors thank Professor K. Rissanen, University of Jyväskylä, Finland, for supplying the tetraethyl resorcarene. Some of the computations presented in this document were made in the computing environment of the Finnish Center for Scientific Computing, which operates under the Ministry of Education.

\section{References}

1. Splitter, J. S.; Tureček, F. Applications of Mass Spectrometry to Organic Stereochemistry. VCH Publishers: New York, 1994; and references within.

2. Desaire, H.; Leary, J. A. Multicomponent Quantification of Diastereomeric Hexosamine Monosaccharides Using Ion Trap Tandem Mass Spectrometry. Anal. Chem. 1999, 71, 4142-4147.

3. Tao, W. A.; Gozzo, F. C.; Cooks, R. G. Mass Spectrometric Quantitation of Chiral Drugs by the Kinetic Method. Anal. Chem. 2001, 73, 1692-1698.

4. Grigorean, G.; Lebrilla, C. B. Enantiomeric Analysis of Pharmaceutical Compounds by Ion/Molecule Reactions. Anal. Chem. 2001, 73, 16841691.

5. Liang, Y.; Bradshaw, J. S.; Izatt, R. M.; Pope, R. M.; Dearden, D. V. Analysis of Enantiomeric Excess Using Mass Spectrometry: Fast Atom Bombardment/Sector and Electrospray Ionization/Fourier Transform 
Mass Spectrometric Approaches. Int. J. Mass Spectrom. 1999, 185-187, 977-988.

6. de Hoffmann, E. Tandem Mass Spectrometry: A Primer. J. Mass Spectrom. 1996, 31, 129-137.

7. Cooks, R. G.; Patrick, J. S.; Kotiaho, T.; McLuckey, S. A. Thermochemical Determinations by the Kinetic Method. Mass Spectrom. Rev. 1994, 13, 287-339.

8. Carlesso, V.; Fournier, F.; Tabet, J.-C. Stereochemical Differentiation of Four Monosaccharides Using Transition Metal Complexes by Electrospray Ionization/Ion-Trap Mass Spectrometry. Eur. J. Mass Spectrom. 2000, 6, 421-428.

9. Speranza, M. Enantioselectivity in Gas-Phase Ion-Molecule Reactions. Int. J. Mass Spectrom. 2004, 232, 277-317.

10. Tabet, J.-C. Fundamentals of Gas Phase Ion Chemistry. Kluwer Academic Publishers: Dordrecht, The Netherlands, 1991; pp 351-372.

11. Brodbelt, J. S. Analytical Applications of Ion-Molecule Reactions. Mass Spectrom. Rev. 1997, 16, 91-110.

12. Vincenti, M. Host-Guest Chemistry in the Mass Spectrometer. J. Mass Spectrom. 1995, 30, 925-939.

13. Sawada, M. Chiral Recognition Detected by Fast Atom Bombardment Mass Spectrometry. Mass Spectrom. Rev. 1997, 16, 73-90.

14. Gal, J. F.; Stone, M.; Lebrilla, C. B. Chiral Recognition of Non-Natural $\alpha$-Amino Acids. Int. J. Mass Spectrom. 2003, 222, 259-267.

15. Ahn, S.; Ramirez, J.; Grigorean, G.; Lebrilla, C. B. Chiral Recognition in Gas-Phase Cyclodextrin: Amino Acid Complexes-Is the Three Point Interaction Still Valid in the Gas Phase? J. Am. Soc. Mass Spectrom. 2001, $12,278-287$.

16. Liang, Y.; Bradshaw, J. S.; Dearden, D. V. The Thermodynamic Basis for Enantiodiscrimination: Gas-Phase Measurement of the Enthalpy and Entropy of Chiral Amine Recognition by Dimethyldiketopyridino-18crown-6. J. Phys. Chem. A. 2002, 106, 9665-9671.

17. Partanen, T.; Pykäläinen, M.; Hulkkonen, H.; Savolainen, O.; Vainiotalo, P. Stereochemical Differentiation of Isomeric Trinorbornane-2,3- and Trinorbornane-2,5-diols by Chemical Ionization Mass Spectrometry. J. Chem. Soc. Perkin Trans. 1994, 2, 1743-1749.

18. Leeck, D. T.; Ranatunga, T. D.; Smith, R. L.; Partanen, T.; Vainiotalo, P.; Kenttämaa, H. Differentiation of Stereoisomeric Diols by Using $\mathrm{CH}_{3} \mathrm{OB}^{+} \mathrm{OCH}_{3}$ in a Small Fourier Transform Ion Cyclotron Resonance Mass Spectrometer. Int. J. Mass Spectrom. Ion Processes. 1995, 141, 229-240.

19. Timmerman, P.; Verboom, W.; Reinhoudt, D. N. Resorcinarenes. Tetrahedron. 1996, 52, 2663-2704.

20. Schneider, H.-J.; Güttes, D.; Schneider, U. A Macrobicyclic Polyphenoxide as Receptor Analogue for Choline and Related Ammonium Compounds. Angew. Chem. Int. Ed. 1986, 25, 647-649.

21. Fülöp, F. The Chemistry of 2-Aminocycloalkanecarboxylic Acids. Chem. Rev. 2001, 101, 2181-2204.

22. de Koning, L. J.; Nibbering, N. M. M.; van Orden, S. L.; Laukien, F. H. Mass Selection of Ions in a Fourier Transform Ion Cyclotron Resonance Trap Using Correlated Harmonic Excitation Fields (CHEF). Int. J. Mass Spectrom. Ion Processes. 1997, 165/166, 209-219.
23. Hop, C. E. C. A.; McMahon, T. B.; Willett, G. D. Determination of Bond Dissociation Energies via Energy-Resolved Collision Induced Dissociation in a Fourier Transform Ion Cyclotron Resonance Spectrometer. Int. J. Mass Spectrom. Ion Processes. 1990, 101, 191-208.

24. Mansikkamäki, H.; Nissinen, M.; Schalley, C. A.; Rissanen, K. SelfAssembling Resorcinarene Capsules: Solid and Gas Phase Studies on Encapsulation of Small Alkyl Ammonium Cations. New J. Chem. 2003, $27,88-97$.

25. Stájer, G.; Szabó, E. A.; Fülöp, F.; Bernáth, G. Stereochemical Studies. 58 Saturated Heterocycles. 39 (1). Preparation and Steric Structures of Dihydro-1,3-Oxazines, 1,3-Oxazin-2-ones and 1,3-Oxazine-2-thiones Fused with Norbornane and Norbornene. J. Heterocyclic Chem. 1983, 20 , 1181-1185.

26. Frisch, M. J.; Trucks, G. W.; Schlegel, H. B.; Scuseria, G. E.; Robb, M. A.; Cheeseman, J. R.; Montgomery, J. A., Jr.; Vreven, T.; Kudin, K. N.; Burant, J. C.; Millam, J. M.; Iyengar, S. S.; Tomasi, J.; Barone, V.; Mennucci, B.; Cossi, M.; Scalmani, G.; Rega, N.; Petersson, G. A. Nakatsuji, H.; Hada, M.; Ehara, M.; Toyota, K.; Fukuda, R.; Hasegawa, J.; Ishida, M.; Nakajima, T.; Honda, Y.; Kitao, O.; Nakai, H.; Klene, M.; Li, X.; Knox, J. E.; Hratchian, H. P.; Cross, J. B.; Bakken, V.; Adamo, C.; Jaramillo, J.; Gomperts, R.; Stratmann, R. E.; Yazyev, O.; Austin, A. J.; Cammi, R.; Pomelli, C.; Ochterski, J. W.; Ayala, P. Y.; Morokuma, K.; Voth, G. A.; Salvador, P.; Dannenberg, J. J.; Zakrzewski, V. G.; Dapprich, S. Daniels, A. D.; Strain, M. C.; Farkas, O.; Malick, D. K.; Rabuck, A. D.; Raghavachari, K.; Foresman, J. B.; Ortiz, J. V.; Cui, Q.; Baboul, A. G.; Clifford, S.; Cioslowski, J.; Stefanov, B. B.; Liu, G.; Liashenko, A.; Piskorz, P.; Komaromi, I.; Martin, R. L.; Fox, D. J.; Keith, T.; Al-Laham, M. A.; Peng, C. Y.; Nanayakkara, A.; Challacombe, M.; Gill, P. M. W. Johnson, B.; Chen, W.; Wong, M. W.; Gonzalez, C.; Pople, J. A. Gaussian03, Revision C.02, Gaussian, Inc.: Wallingford, CT, USA, 2004.

27. Mäkinen, M.; Jalkanen, J.-P.; Vainiotalo, P. Conformational Properties and Intramolecular Hydrogen Bonding of Tetraethyl Resorcarene: An $\mathrm{Ab}$ Initio Study. Tetrahedron. 2002, 58, 8591-8596.

28. Mäkinen, M.; Rissanen, K.; Vainiotalo, P. Alkali Metal Mediated Resor carene Capsules: An ESI-FTICRMS Study on Gas-Phase Structure and Cation Binding of Tetraethyl Resorcarene and its Per-methylated Derivative. J. Am. Soc. Mass Spectrom. 2002, 13, 851-861.

29. GaussView 3.0 User's Reference. Gaussian, Inc.: Wallingford, CT, USA

30. Mäkinen, M.; Nissinen, M.; Rissanen, K.; Vainiotalo, P. Ammonium Ion Mediated Resorcarene Capsules: ESI-FTICRMS Study on Gas-Phase Structure and Ammonium Ion Affinity of Tetraethyl Resorcarene and Its Per-Methylated Derivative. J. Am. Soc. Mass Spectrom. 2003, 14, 143-151.

31. Letzel, M. C.; Decker, B.; Rozhenko, A. B.; Schoeller, W. W.; Mattay, J. Encapsulated Guest Molecules in the Dimer of Octahydroxypyridine[4]arene. J. Am. Chem. Soc. 2004, 126, 9669-9674.

32. Macias, A. T.; Norton, J. E.; Evanseck, J. D. Impact of Multiple Cation- $\pi$ Interactions upon Calix[4]arene Substrate Binding and Specificity. J. Am. Chem. Soc. 2003, 125, 2351-2360.

33. Mäkinen, M.; Jalkanen, J.-P.; Vainiotalo, P. Ammonium Ion Complexes of Tetraethyl Resorcarene: An Ab Initio Study. Supramol. Chem. 2005, 17, 377-381. 